\title{
Built environment design-economic sustainability relationship in urban renewal
}

\author{
S. Y1ldiz ${ }^{*}$, S. Kivrak ${ }^{2}$ and G. Arslan ${ }^{2}$ \\ ${ }^{1}$ Turkish Military Academy, Department of Civil Engineering, Ankara, Turkey \\ ${ }^{2}$ Anadolu University, Department of Civil Engineering, Eskişehir, Turkey
}

\begin{abstract}
Like in many other developing countries, urban renewal projects constitute a significant part of the activities of architecture, engineering, and construction (AEC) industry in Turkey, and recently Turkey has started an urban renewal movement aiming renewal of 8 million dwellings. In this study, as a critical factor on the success and continuity of the urban renewal projects, the relation between built environment design and economic sustainability in urban renewal areas, was examined. In order to determine the importance of built environment design elements in terms of economic sustainability, a survey study was done with the participation of 323 people, who were mainly architects, civil engineers, and urban planners and have previously worked in urban renewal projects. By applying factor analyses the design elements were grouped under six different factors, which were named as: Transportation and Accessibility, Built Environment Quality, Conservation of Resources, Supporting Social Life, Commercial and Economic Opportunities and Historical and Cultural Values. The importance weights of these factors were determined by AHP analyses conducted with the participation of a group of 60 people formed by academicians and practitioners. Conservation of Resources and Commercial and Economic Opportunities factors were found as the most important factors. It is evaluated that the results of the study will guide the urban renewal stakeholders in creating economically sustainable urban renewal areas.
\end{abstract}

\section{Keywords}

Urban renewal; Economic sustainability; AHP analysis; Factor analysis

Received: 15 March 2018; Accepted: 24 March 2018

ISSN: 2630-5771 (online) (C) 2018 Golden Light Publishing All rights reserved.

\section{Introduction}

In the past century, rapid population growth and migration from rural to urban areas caused an uncontrolled urban growth in Turkey, like in many other developing countries. This process resulted in an unmanaged and unplanned urbanization, and cities were filled with disaster vulnerable and unhealthy houses and slums. Meanwhile, urban aging has also resulted in an environmental degradation, more unhealthy buildings, and economically and socially more negative physical surroundings. All of these problems necessitate urban renewal practices that express planned intervention in the built environment, and a major urban renewal movement has recently been started in Turkey in order to renew about 8 million dwellings. However, urban renewal is mainly considered in Turkey as the physical renewal of buildings. Even though physical renewal increases the quality of the built environment and the quality

* Corresponding author

Email: syildiz@kho.edu.tr 
of life of citizens to a certain extent, in the long run, the society is negatively affected, since the balance between social, economic and environmental aspects is not established [1].

To ensure the success of urban renewal projects, in the long run, a different perspective is needed. According to its contemporary definition, urban renewal is regarded as a sound approach to promoting land values, improving environmental quality; rectifying the urban decay problem, meeting various socioeconomic objectives; enhancing existing social networks, and changing adverse impacts on the living environment. Since sustainable development corresponds to the urban renewal that deals with all these issues in terms of economic, social and environmental sustainability [2], and since sustainability debates become more meaningful when associated with space [3], urban renewal and sustainability should be addressed together. With a sustainable urban renewal, the harmonization between socioeconomic interests and concerns about environment and energy could be ensured [4], thus environmental, social and economic costs of urban development could be reduced [5].

Economic sustainability, which was discussed in this study, is as important as the other two dimensions of sustainability. Pearce [6] defined economic sustainability as the growth of the economic system in a continuous and developing manner in its own indicators and as the creation of income and employment especially for the sustainability of population without threatening by biophysical and social impacts. It involves a variety of strategies that allow the most advantageous use of available resources, and it is extremely important to establish and maintain the necessary financial resources to realize environmental and social sustainability in urban areas [7]. Urban renewal could serve the economic sustainability in the long run in various ways like increasing the attractiveness of the region and thus increasing rental and sale values of the properties, attracting additional investment to the region, increasing employment by revealing new business areas, reducing expenses by providing savings from the use of any source, and by improving the economic situation of the citizens and the workforce living in that area $[8,9,10]$. In this respect, many different built environment design elements, such as mixeduse, transportation systems, open spaces, public facilities, energy efficient buildings, will directly or indirectly affect the economic sustainability of urban renewal areas.

From this point of view, in this study, in urban renewal, the relation between built environment design and economic sustainability was examined. With a survey study, the contribution of design elements to economic sustainability was evaluated. The design elements were grouped by factor analysis and the relation between these factors and economic sustainability was discussed. The importance weights of the factors were determined with AHP analyzes. The results of the study give some clues to AEC sector professionals along with the other urban renewal stakeholders, in order to ensure the economic sustainability of urban areas which is critical to the success and continuity of urban renewal projects.

\section{Material and method}

A good understanding of the relationship between built environment and economic sustainability is crucial, in order to be able to contribute to economic sustainability through the redesign and rebuilding of the built environment. This study aimed to determine the design elements and their importance weights that will contribute to the economic sustainability of renewal areas.

\subsection{Identification of design elements and pilot study}

The sustainability of an urban renewal project is absolutely linked to the sustainability of the design elements. For sustainable design elements, Kim and Rigdon [11] developed a guiding conceptual framework, which is constituted of three principles (conservation of resources, life-cycle design, and human design), strategies related to these principles and methods related to these strategies. In this study, by adding the proposals of some other researchers $[9,12,13,14]$ to the methods proposed 
in this conceptual framework, 50 design elements were listed to measure their contribution to economic sustainability.

Since it is beneficial to perform a pilot study before a wide-scale study in order to make revisions in the direction and target of the study and to simplify the questions, a pilot study was conducted face to face with 20 people. They were professionals working in TOKI (Housing Development Administration of Turkey) and in charge of urban renewal projects in Istanbul. The participants evaluated the importance of design elements in terms of their contribution to the economic sustainability of urban renewal area, on a five-point Likert-type scale. The participants stated that some design elements had very close meanings to each other. Therefore, the correlations between design elements were examined, and by combining the elements with strong correlation, the number of the design elements was reduced to 32 in the main study.

\subsection{Survey study}

Since the subject of the study requires having information about sustainability and urban renewal concepts, purposive sampling method was used and participants were selected from public and private sector professionals, who were involved in urban renewal projects previously. The sample size was determined based on the number of samples required for an effective factor analysis. Some researchers argue that the number of samples should be numbers such as 100, $150-300,200,250$ $[15,16]$, while some others argue that this number should be taken as a ratio to the variable number like $3: 1,5: 1,10: 1$ or $20: 1[16,17,18]$. Accordingly, the sample size of 323 in this study was sufficient for factor analysis. With this research, 32 design element's contributions to the economic sustainability of an urban renewal project were evaluated by 323 participants in a 5-point Likert scale. Some of the demographic data of the participants were given in Table 1. The results were analyzed with Statistical Package for Social Science (SPSS) 21.0.
Table 1. Demographic data of the participants

\begin{tabular}{|c|c|c|c|}
\hline & & Frequency & Percent $(\%)$ \\
\hline \multirow{2}{*}{ Gender } & Male & 205 & 63.5 \\
\hline & Female & 118 & 36.5 \\
\hline \multirow{5}{*}{ Profession } & Architect & 58 & 18.0 \\
\hline & $\begin{array}{l}\text { Civil } \\
\text { Engineer }\end{array}$ & 122 & 37.8 \\
\hline & $\begin{array}{l}\text { City and } \\
\text { Regional } \\
\text { Planning }\end{array}$ & 73 & 22.6 \\
\hline & $\begin{array}{l}\text { Geomatic } \\
\text { Engineer }\end{array}$ & 27 & 8.4 \\
\hline & Others & 43 & 13.3 \\
\hline \multirow{3}{*}{$\begin{array}{l}\text { City } \\
\text { inhabited }\end{array}$} & Ankara & 185 & 57.3 \\
\hline & Istanbul & 109 & 33.7 \\
\hline & Others & 29 & 9.0 \\
\hline \multirow{4}{*}{$\begin{array}{l}\text { Work } \\
\text { Experience }\end{array}$} & $\begin{array}{l}\text { Less than } \\
5 \text { years }\end{array}$ & 123 & 38.1 \\
\hline & $5-14$ & 133 & 41.2 \\
\hline & $15-24$ & 52 & 16.1 \\
\hline & $\begin{array}{l}25 \text { years } \\
\text { and above }\end{array}$ & 15 & 4.6 \\
\hline
\end{tabular}

Cronbach's alpha coefficient value shows the consistency of answers, and while 0,5 indicates sufficient [19], values above 0.9 indicate high reliability [20]. It was found as 0.929 in this study.

\section{Statistical analysis and results}

\subsection{Inferential analysis}

To examine whether there were any significant differences between the participants' views on the contributions of the design elements to economic sustainability, in this study two statistical techniques were used. The independent-samples ttest compares the means between two unrelated groups on the same continuous, dependent variable, while the one-way analysis of variance is used to determine whether there are any statistically significant differences between the means of three or more unrelated groups. As a result of the tests, significant differences were found only according to professions at two design elements, which are "Implementation of mixed-use development model" and "Protection of local features". 
Since significant differences were found in very few design elements, it was concluded that there was a general consensus among participants, thus the results could be generalized.

\subsection{Factor analysis and evaluation of the factors}

Factor analysis is a statistical method used to describe variability among observed, correlated variables in terms of a potentially lower number of unobserved variables, called factors. In this study to ensure the easier understanding and interpretation of the results, exploratory factor analysis was carried out by examination of the suitability of sample to factor analysis, performing basic component analysis, rotating the factor axes, and performing reliability analysis.

There are different ways of controlling the suitability of samples for the factor analysis, that is to say, their factorability. The Kaiser-Meyer-Olkin (KMO) and Barlett's tests are most commonly used among them. The KMO score was found as 0.917 which refers to excellent [21] and Bartlett's test result was found as significant which refers to good suitability [22]. In the basic component analysis, it is suggested to remove the variables whose load value difference was below 0.10 or whose load value was under accepted threshold load value $(0.4$ in this study) [23]. In this study, 5 design elements were removed from the analysis respectively. To synchronize the relative importance of the factors, the factor axes were rotated, and it was found 6 factors with eigenvalues greater than 1 , which explain $59 \%$ of the total variance (Table 2). An analysis describing $50-75 \%$ of the total variance is considered good [24].

At the final stage of the factor analysis, the reliability analysis was performed to measure the consistency of responses. Cronbach's alpha coefficient value of all factors found greater than 0.7 , which referred to quite reliability of the factors [19].

In a factor analysis, the extracted factors should be named by examining the variables that load the factors, and by determining the common point between them. A well-named factor provides an accurate, useful description of the underlying construct. In this study, the six factors were named as follows.

Factor 1:

The design elements, gathered under the first factor, were mainly related to the resident's transportation and access opportunities (Table 3), thus it was named as transportation and accessibility. The factor loadings of the variables given on the last column of the table is a measure of how much the variable contributes to the factor; thus, high factor loading scores indicate that the dimensions of the factors are better accounted for by the variables. In urban areas, high road traffic volume, and congestion lead to a reduction in the efficiency of transport, and an increase in the costs of handling and transportation [25].

Table 2. Factors and explained total variance

\begin{tabular}{|c|c|c|c|c|c|c|}
\hline \multirow{2}{*}{$\begin{array}{c}\text { Component } \\
\text { (Factor) }\end{array}$} & \multicolumn{3}{|c|}{ Extraction Sums of Squared Loadings } & \multicolumn{3}{|c|}{ Rotation Sums of Squared Loadings } \\
\hline & Total & $\%$ of Variance & Cumulative $\%$ & Total & $\%$ of Variance & Cumulative $\%$ \\
\hline 1 & 8.588 & 31.808 & 31.808 & 3.106 & 11.505 & 11.505 \\
\hline 2 & 2.311 & 8.559 & 40.367 & 2.995 & 11.093 & 22.599 \\
\hline 3 & 1.548 & 5.732 & 46.099 & 2.814 & 10.421 & 33.020 \\
\hline 4 & 1.211 & 4.486 & 50.585 & 2.482 & 9.192 & 42.212 \\
\hline 5 & 1.168 & 4.326 & 54.911 & 2.449 & 9.072 & 51.283 \\
\hline 6 & 1.019 & 3.774 & 58.685 & 1.998 & 7.401 & 58.685 \\
\hline
\end{tabular}


Table 3. Transportation and accessibility factor and factor loads

\begin{tabular}{llll}
\hline No & Design Element & Load \\
\hline DE10 & $\begin{array}{l}\text { Efficient, suitable and safe designs } \\
\text { for pedestrians and public }\end{array}$ & .687 \\
transportation & $\begin{array}{l}\text { Efficient, suitable and safe design for } \\
\text { drivers }\end{array}$ & .642 \\
DE7 & $\begin{array}{l}\text { Providing open spaces and ensuring } \\
\text { easy access to them }\end{array}$ & .633 \\
DE13 & $\begin{array}{l}\text { Facilities for disabled, elderly and } \\
\text { children }\end{array}$ & .630 \\
DE18 & $\begin{array}{l}\text { Providing public facilities and } \\
\text { ensuring easy access to them }\end{array}$ & .615 \\
DE14 & $\begin{array}{l}\text { Suitable design for disabled, elderly } \\
\text { and children }\end{array}$ & .571 \\
\hline
\end{tabular}

According to Dizdaroglu and Yigitcanlar [8], good public transport brings out sustainable regions by providing the opportunity to reach the desired place more easily, and in a shorter time. In this respect, an effective transportation system is a necessary element for a successful economy. Public spaces and facilities contribute to economic sustainability of the region, by attracting companies, therefore, customers, employees, and services [26]. Since the needs of disabled, elderly and children are nowadays taken into account in investment preferences [27], it is also important for the economic sustainability of the area.

Factor 2:

Factor 2, constituted from 6 design elements given in Table 4, was named as the quality of the built environment. Design features offered by urban area affect the value of it since people are becoming willing to pay more along with the increasing aesthetics and functionality [28]. According to Cilliers [29], unattractive areas will be useless and a high-quality public space creates a significant impact on the economic life of the city. It is clear that a good landscape design will contribute to the local economy by increasing house prices, as buyers prefer to live next to green areas [26]. Finally, high-density use of land supports economic sustainability by decreasing automobile travels and travel costs as well as decreasing the depreciation of infrastructure investments such as water, sewerage, and electricity [5].

Factor 3:

The third factor was named as the conservation of resources (Table 5). Energy efficiency has become a key element of the building performance measurement as buildings are responsible for approximately $40 \%$ of global energy consumption [30], and this will serve to economic sustainability by providing savings from expenses. It is possible to reduce water consumption and to provide financial savings with many simple precautions that can be applied to new buildings. Material conservation contributes to economic sustainability by helping to reduce the expenses required for the production and transport of materials [9]. Rahman [31] argues that buildings with optimized indoor environmental quality are valued $\sim 3-7 \%$ higher for sale and rental, and operating costs are $13-15 \%$ lower.

Factor 4:

The fourth factor was named as the support of social life (Table 6). Iverot and Brandt [32] argue that the participation of all relevant groups in the decisionmaking process is indispensable for sustainability, and the success of the decisions depends on development, application, and realization at the local level. Crime strengthens social exclusion and makes people reluctant to walk and to use public transport, in consequence, the occupants, potential owners, and the investors are willing to pay more for the developments having a harmonious and safe environment $[25,33]$.

Table 4. Quality of built environment factor and factor loads

\begin{tabular}{lll}
\hline No & Design Element & Load \\
\hline DE29 & $\begin{array}{l}\text { Establishment of appropriate } \\
\text { structural forms }\end{array}$ & .745 \\
DE30 & Compliance with environment & .665 \\
DE32 & High density use of land & .630 \\
DE28 & Good landscaping & .586 \\
DE31 & $\begin{array}{l}\text { Appropriate layout of buildings and } \\
\text { streets }\end{array}$ & .556 \\
DE27 & $\begin{array}{l}\text { Applying waste management and } \\
\text { pollution control }\end{array}$ & .512 \\
\hline
\end{tabular}


Table 5. Conservation of resources factor and factor loads

\begin{tabular}{lllll}
\hline No & Design Element & & & Load \\
\hline DE1 & $\begin{array}{l}\text { Energy conserving } \\
\text { construction }\end{array}$ & design & and & .765 \\
DE2 & $\begin{array}{l}\text { Water conserving } \\
\text { construction }\end{array}$ & design & and & .734 \\
DE3 & $\begin{array}{l}\text { Material conserving } \\
\text { construction }\end{array}$ & design & and & .707 \\
DE8 & $\begin{array}{l}\text { Efficient use of land } \\
\text { DE4 }\end{array}$ & $\begin{array}{l}\text { Design of structures } \\
\text { human comfort }\end{array}$ & to increase & .492 \\
\hline
\end{tabular}

Table 6. Support of social life factor and factor loads

\begin{tabular}{llc}
\hline No & Design Element & Load \\
\hline DE23 & $\begin{array}{l}\text { Ensuring community participation in } \\
\text { public decisions }\end{array}$ & .755 \\
DE22 & $\begin{array}{l}\text { Promoting communication and } \\
\text { creating a sense of community }\end{array}$ & .704 \\
DE21 & Taking security measures & .681 \\
\hline
\end{tabular}

Factor 5:

The fifth factor was named as commercial and economic opportunities (Table 7). Providing local employment and ensuring housing opportunities for different income groups will be good for the economy as it will attract a population supporting local economic activities with employment, regular consumption, and expenditure [10]. Implementation of mixed-use model, establishment of local commercial activity areas such as shops, banks, cafes, and diversification of these commercial activities will increase the employment, decrease in need for car usage, increase vitality, promote day and evening activities, attract potential residents, increase the number of people in circulation and their interaction, and match energy supplies for peak demands [9, 14, 34], which will directly or indirectly contribute to economic sustainability of the region.

Factor 6:

The sixth factor composed of two elements was named as historical and cultural values (Table 8). The preservation of historical structures and local characteristics will make the region a tourist
Table 7. Commercial and economic opportunities factor and factor loads

\begin{tabular}{|c|c|c|}
\hline No & Design Element & Load \\
\hline DE17 & $\begin{array}{l}\text { Establishment of various commercial } \\
\text { activities }\end{array}$ & .747 \\
\hline DE25 & $\begin{array}{l}\text { Ensuring housing opportunities for } \\
\text { different income groups }\end{array}$ & .595 \\
\hline DE16 & Providing local employment & .591 \\
\hline DE11 & $\begin{array}{l}\text { Implementation of mixed-use } \\
\text { development model }\end{array}$ & .588 \\
\hline DE12 & Flexible design of buildings & .564 \\
\hline
\end{tabular}

Table 8. Historical and cultural values factor and factor loads

\begin{tabular}{llc}
\hline No & Design Element & Load \\
\hline DE26 & Preservation of historical structures & .755 \\
DE24 & Protection of local features & .609 \\
\hline
\end{tabular}

destination and will increase sale and rental values of the properties [27]. According to Cilliers [29], historical structures and local features will create unique areas for branding the city, resulting in economic consequences like high investment and market value.

\subsection{AHP analysis}

In order to determine the importance weights of the factors, AHP analysis was performed. AHP is a frequently used decision-making and forecasting method because of its features such as simplicity, flexibility, ease of use and comfortable interpretation, and gives the percentage distributions of decision points in terms of factors affecting decision [35]. In this method, participants make binary comparisons based on four axioms. The first axiom, the reciprocal axiom, requires that, if $\mathrm{PC}(\mathrm{A}, \mathrm{B})$ is a paired comparison representing how many times more the element $A$ possesses a property than does element $\mathrm{B}$, then $\mathrm{PC}(\mathrm{B}, \mathrm{A})=$ $1 / \mathrm{PC}(\mathrm{A}, \mathrm{B})$. The second, or homogeneity axiom, states that the elements being compared should not differ by too much, else there will tend to be larger errors in judgment. The third, synthesis axiom states that judgments about the priorities of the elements in a hierarchy do not depend on lower level elements. The fourth expectation axiom, says 
that individuals who have reasons for their beliefs should make sure that their ideas are adequately represented for the outcome to match these expectations [36]. The method is implemented in five stages. The first stage is identifying the problem and determining the evaluation criteria. The second stage is the creation of binary comparison matrices in order to determine the weights. The comparison of the criteria is made by the experts of the subject, and the importance of the criteria is compared using the importance scale from Table 9. The comparison matrix can be formed as the decision that the experts will take as a group, or by taking the geometric mean of the results taken separately from each expert. The third stage is the determination of weights distribution of factors, which is specified by the eigenvectors of the binary comparison matrices. The next stage is to calculate a Consistency Ratio (CR) to measure how consistent the judgments have been. If the CR is much in excess of 0.1 the judgments are untrustworthy because they are too close for comfort to randomness. The last stage, which was not used in this study since any decision problem was not solved, is the determination of the rankings of the alternatives [36, 37, 38].

In this study, the AHP analysis was performed with the participation of 60 people. About half of the participants were urban renewal practitioners, who had already participated in previous survey study, and the other half were academicians. 25 of the participants were residing in Istanbul and 35 in Ankara. The study was carried out in February 2016 by using a clear and understandable question form, since it was difficult to gather so many participants together.
Table 9. Importance scale

\begin{tabular}{lll}
\hline $\begin{array}{l}\text { Intensity of } \\
\text { importance }\end{array}$ & Definition & Explanation \\
\hline 1 & $\begin{array}{l}\text { Equal } \\
\text { importance } \\
\text { Somewhat more } \\
\text { important } \\
\text { Much more } \\
\text { important }\end{array}$ & $\begin{array}{l}\text { Two factors contribute } \\
\text { equally to the objective. } \\
\text { Slightly favour one over } \\
\text { the other. }\end{array}$ \\
5 & $\begin{array}{l}\text { Strongly favour one over } \\
\text { the other. }\end{array}$ \\
7 & $\begin{array}{l}\text { Very much } \\
\text { more important }\end{array}$ & $\begin{array}{l}\text { Very strongly favour } \\
\text { one over the other. }\end{array}$ \\
9 & $\begin{array}{l}\text { Absolutely } \\
\text { more important }\end{array}$ & $\begin{array}{l}\text { Favouring is of the } \\
\text { highest possible validity. } \\
\text { When compromise is }\end{array}$ \\
$2,4,6,8$ & $\begin{array}{l}\text { Intermediate } \\
\text { values }\end{array}$ & $\begin{array}{l}\text { needed. } \\
\text { nalues }\end{array}$ \\
\hline
\end{tabular}

The comparison matrix, which is given in Table 10, was formed by taking the geometric mean of the results taken separately from each participant. The internal CR of the matrix was found to be 0.005 , which is well below the recommended limit value 0.1 by Saaty [36].The eigenvectors, which gave the importance weights of the factors, were determined as Transportation and Accessibility (TA) 15\%, Built Environment Quality (BEQ) 14\%, Conservation of Resources (CR) 21\%, Supporting the Social Life (SSL) 15\%, Commercial and Economic Opportunities (CEO) 20\% and Historical and Cultural Values (HCV) 16\%. Although the conservation of resources and commercial and economic opportunities factors seem more weighted, all factors gained importance weights over a certain level.

\section{Discussion and recommendation}

According to the results of the study, various recommendations can be presented in order to increase the economic sustainability of urban renewal areas.

Table 10. Economic sustainability factors paired comparisons

\begin{tabular}{cccccccc}
\hline & TA & BEQ & CR & SSL & CEO & HCV & Eigenvector \\
\hline TA & 1.00 & 2.17 & 0.58 & 0.68 & 0.80 & 0.60 & 0.15 \\
BEQ & 0.46 & 1.00 & 0.49 & 0.51 & 0.56 & 0.47 & 0.14 \\
CR & 1.71 & 2.06 & 1.00 & 1.28 & 1.09 & 1.01 & 0.21 \\
SSL & 1.48 & 1.96 & 0.78 & 1.00 & 1.08 & 0.96 & 0.15 \\
CEO & 1.26 & 1.77 & 0.92 & 0.93 & 1.00 & 0.82 & 0.20 \\
HCV & 1.65 & 2.13 & 0.99 & 1.04 & 1.21 & 1.00 & 0.16 \\
\hline
\end{tabular}


Based on the analysis, conservation of resources was found as the most important factor, with an importance weight of $21 \%$. Electricity and heating expenses have a high share in both Turkey's and family budgets since Turkey is an externally dependent country on energy raw materials. Furthermore, it is anticipated that Turkey will become a water-poor country in the near future. In this respect, it is important to construct energy, water, and material efficient buildings for economic sustainability. The easiest way to achieve this would be to provide both incentives and regulations for the construction of green buildings.

Economy and trade factor was found as the second most important factor. It is clear that all the elements that were gathered under this factor will make the renewal area economically more viable and will positively affect the economic sustainability. Therefore, mixed-used development model should be used, and beside dwellings, it is necessary to plan easily accessible commercial areas and public facilities in urban renewal areas.

Transportation and accessibility are also important for the economic sustainability of a region. Unplanned density increase in most of the urban renewal projects causes significant traffic problems. Urban renewal projects should be planned together with a comprehensive transportation assessment plan, which addresses issues such as pedestrian sidewalks, parking lots, public transport arrangements, current traffic flows and projected improvements, school and bicycle routes. To increase the accessibility of all residents, especially the elderly, children and the disabled, open spaces and public facilities should be planned in urban renewal area.

Built environment quality is another important factor for economic sustainability of urban renewal area since this will increase the attractiveness of the area, therefore, the real estate sale and rental values. To achieve this, a guide to the area's landscape and to the surroundings should be prepared, and the appearances, heights, densities, and volumes of the buildings could be planned properly within this context.
Supporting social life factor is important in terms of economic sustainability, as it affects the general success of the project and preference of the area. In general to succeed, before starting the design it is necessary to come together with citizens, business owners, residents, and employees to receive and document their views. Consultation meetings could be organized to plan public spaces where social interaction can take place. Taking into account that people want to live in safe places, measures such as the establishment of police stations, the provision of adequate lighting and the installation of security cameras should be planned.

The elements of preservation of historical structures and local features, that constitute the historical and cultural values factor, positively affect the economic sustainability by increasing the value of the area and also by contributing to tourism. For this reason, conservation and adaptive use of historic buildings in the area should be targeted, and a study should be conducted to determine the local identity of the area. To strengthen local identity, some measures could be taken such as the use of local materials, compliance with local architectural characteristics, and the use of native plant species.

\section{Conclusion}

Urban renewal projects constitute an important part of the business volume of the AEC sector in Turkey, like many other developing countries. Successful implementation of urban renewal projects is of great importance both for the continuity of the sector's business in this area and for the permanent resolution of urban problems resulting from rapid and unplanned urbanization. Contemporary approaches argue that this can be achieved by realizing the urban renewal in accordance with sustainability principles. In this study, the economic dimension of sustainability, which is also crucial in terms of the creation of financial resources for urban renewal, has been discussed. Firstly the built environment design elements that would come to the fore in an urban renewal project were identified. These design elements were evaluated by a survey study 
according to their contributions to economic sustainability and were collected on six different factors by factor analysis. AHP analysis was carried out to determine the importance weights of these factors.

The results of this study clearly and simply reveal the relationship between the built environment design and economic sustainability, and also indicate to what extent the factors are important in terms of economic sustainability. It is expected that the results of the study will guide a wide range of urban renewal stakeholders, consisting contractors, project designers, engineers, policy makers, planners, residents and local administrators. Since sustainability is a universal concept in principle, it is possible to say that, the results of this study could be utilized in urban renewal projects conducted all over the world. On the other hand, each country has its own specific characteristics and needs, which may change at least the weights of the factors. In order to compare the results and demonstrate the generalizability of them, it would be appropriate to repeat the work in the smaller cities of Turkey and also in different countries of the world.

\section{Acknowledgments}

This work was supported by Anadolu University Scientific Research Projects Commission under the grant number 1505F505.

\section{References}

[1] Yoke-Lian L, Hassim S., Muniandy R., Teik-Hua L. Review of Subcontracting Practice in Construction Industry. IACSIT International Journal of Engineering and Technology 4(4) (2012) 442-445.

[2] Tang B. S. From Privatization to Bureaucratization: Implementing Urban Renewal in Hong Kong. Planning in a Global Era. Aldershot, UK: Ashgate, 2002.

[3] Zheng H. W, Shen G. Q., Wang H. A review of recent studies on sustainable urban renewal. Habitat International, 41 (2014) 272-279.

[4] Wood A. P., Bruff G. E. Local sustainable development:land-use planning's contribution to modern local government. Journal of
Environmental Planning and Management, 43(4) (2000) 519-539.

[5] Cloutier S., Larson L., Jambeck J. Are sustainable cities "happy" cities? Associations between sustainable development and human well-being in urban areas of the United States. Environment, Development and Sustainability, 16(3) (2014) 633647.

[6] Musakwa W., Van Niekerk A. Monitoring sustainable urban development using built-up area indicators: a case study of Stellenbosch, South Africa. Environment, Development and Sustainability, 17(3) 547-566, 2015.

[7] Pearce D. Optimal prices for sustainable development. In Economics, Growth and Sustainable Environments London: Palgrave Macmillan Press, 1988.

[8] Gilbert R., Stevenson D., Girardet H., Stren R. Making cities work. London: Earthscan, 1996.

[9] Dizdaroglu D., Yigitcanlar T. A. Parcel-scale assessment tool to measure sustainability through urban ecosystem components: The MUSIX model, Ecological Indicators, 41 (2014) 115-130

[10] Kent Association of Local Authorities (KALA), Kent Design A Guide to Sustainable Development Available from the Internet:

https://shareweb.kent.gov.uk/Documents/ community-and-living/Regeneration/kent-designguide-2000.pdf, 2000.

[11] Oktay D. Urban design for sustainability: a study on the Turkish city. International Journal of Sustainable Development and World Ecology 11(1) (2004) 24-35.

[12] Kim J. J., Rigdon B. Sustainable Architecture Module: Introduction to Sustainable Design, National Pollution Prevention Center for Higher Education, Michigan, 1998.

[13] Newman P. W. G., Kenworthy J. Sustainability and Cities: Overcoming Automobile Dependence. Washington, DC: Island Press, 1999.

[14] Wheeler S. Planning sustainable and livable cities, The city reader, 2 (1998) 434-445.

[15] CABE and DETR (Department of the Environment, Transport and the Regions) The value of urban design: A research project commissioned by CABE and DETR to examine the value added by good urban design. London: Thomas Telford, 2001.

[16] MacCallum R. C., Widaman K. F., Zhang S., Hong S. Sample size in factor analysis. Psychological Methods 4 (1999) 84-99. 
[17] Gorsuch R. L. Factor analysis (2nd ed.). Hillsdale, NJ: Erlbaum, 1983.

[18] Bryant F. B., Yarnold P. R. Principal components analysis and exploratory and confirmatory factor analysis. In L. G. Grimm \& R R. Yarnold (Eds.), Reading and understanding multivariate statistics (pp. 99-136). Washington, DC: American Psychological Association, 1995.

[19] Garson D. G. Factor Analysis: Statnotes. North Carolina State University Public Administration Program, Available from Internet: http://www2.chass.ncsu.edu/garson/pa765/factor.h tm., 2008

[20] Cronbach L. J. Coefficient alpha and the internal structure of tests. Psychometrika, 16(3) (1951) 297334.

[21] Murphy K. R., Davidshofer C. O. Psychological testing. 4th Edition, New Jersey: Prentice - Hall Inc, 1998.

[22] Hutcheson G. D., Sofroniou N. The multivariate social scientist: Introductory statistics using generalized linear models. Sage Pub, London, UK, 1999.

[23] Snedecor G. W., Cochran W. G. Failures in the assumptions. Statistical methods, (1989) 278-280.

[24] Thompson B. Exploratory and confirmatory factor analysis: Understanding concepts and applications. American Psychological Association, 2004.

[25] Tabachnick B. G., Fidell L. S. Principal components and factor analysis. In Using multivariate statistics, 4th ed., Needham Heights, MA: Allyn \& Bacon, 2001.

[26] Sustainable Environment, [online], [cited 23.03.2017]. Available from Internet http://www.sustainable-environment.org.uk), 2016.

[27] Gedikli B. The Open Space Contributing to Neighborhood Sustainability Through Public Events: A Case From Ankara Turkey Available from the Internet: http://www.livablecities.org/sites/ default/files/papers/Gedikli-Bahah-(paper).pdf, 2010.

[28] Song Y., Knaap G. New Urbanism and Housing Values: A Disaggregate Assesment, Journal of Urban Economics 54 (2003) 218-238.

[29] Cilliers E. J., Timmermans W., van den Goorbergh, F., Slijkhuis J. S. A. Designing public spaces through the lively planning integrative perspective. Environment, Development and Sustainability 17(6) (2015) 1367-1380.
[30] Motawa I., Carter K. Sustainable BIM-based evaluation of buildings, 26th IPMAWorld Congress Crete Greece, Procedia-Social and Behavioral Sciences 74 (2013) 419-428.

[31] Rahman M. M. G., Megat A., Maryanti M. R. Impacts of Indoor Environmental Quality (IEQ) Elements on Residential Property Market: A Review. Jurnal Teknologi 73(5) (2015) 42-45.

[32] Iverot S. P., Brandt N. The development of a sustainable urban district in Hammarby Sjöstad, Stockholm, Sweden. Environment, Development and Sustainability 13(6) (2011) 1043-1064.

[33] Lee G. K. L., Chan E. H. W. Factors affecting urban renewal in high-density city: Case study of Hong Kong. Journal of Urban Planning and Development -ASCE 134(3) (2008) 140-148.

[34] Lee J. S. Enhancing sustainability in downtown by triple-value adding to urban redevelopment efforts: A case study of Seoul, Korea. PhD Thesis Washington: University of Washington, 2003.

[35] Saaty T. L. The Analytic Hierarchy Process, New York: McGraw Hill, 1980.

[36] Saaty T. L. Axiomatic foundations of the AHP, Management Science 32 (1986) 841- 855.

[37] Saaty T. L., Peniwati K. Group Decision Making: Drawing out and Reconciling Differences. Pittsburgh, Pennsylvania: RWS Publications, 2008.

[38] Bhushan N., Kanwal R. Strategic Decision Making: Applying the Analytic Hierarchy Process. London: Springer-Verlag, 2004. 